\title{
ENHANCING LIFELONG LEARNING AWARENESS IN THE FACULTY OF ENGINEERING AT MCGILL UNIVERSITY
}

\author{
Maria Orjuela-Laverde, Nasim Razavinia, and Laurent Mydlarski \\ Faculty of Engineering, McGill University \\ maria.orjuela-laverde@mcgill.ca \\ nasim.razavinia@mcgill.ca \\ laurent.mydlarski@mcgill.ca
}

\begin{abstract}
The theoretical approach to Lifelong Learning used in this paper introduces findings in the field of Self-Regulated Learning (SRL). We are using Nilson's [4] definition of SRL, which states that selfregulation "encompasses the monitoring and managing of one's cognitive processes, as well as the awareness of and control over one's emotions, motivations, behavior, and environment as related to learning." The principles that guide SRL, as proposed by Schunk and Zimmerman [6-8] are: 1) Forethought; 2) Performance/volitional control and; 3) Self-reflection. Following the definition and principles suggested in the SRL literature, activities were designed to develop and strengthen engineering students' self-regulated learning skills and awareness of such competencies. At McGill University, the Faculty of Engineering is pursuing a systematic assessment method of lifelong learning awareness by the way of activities that target the first-and final-year students.
\end{abstract}

Keywords: Lifelong Learning Awareness, Self-Regulated Learning, Motivated Strategies for Learning Questionnaire (MSLQ), Active Learning.

\section{INTRODUCTION}

This paper describes activities implemented in the Faculty of Engineering, at McGill University, designed to measure students' perceptions of skills obtained to become lifelong learners. Design of the activities and the tools used to measure perceptions on lifelong learning skills were conducted using as a theoretical framework Self-Regulated Learning (SRL). McGill's Faculty of Engineering has invested, in the past 5 years, substantial resources to enhance teaching and learning using studentcentered pedagogies. Examples of these activities are peer-instruction, flipped classrooms, and peer-assessment. The Faculty's short- and medium-term goals are to measure how the use of these strategies are influencing the development of SRL academic skills within our student population. Current efforts in this field have been to measure students' perceptions on how their experiences at the Faculty of Engineering have helped develop their SRL skills. This paper describes activities designed and implemented to measure such perceptions, as well as a survey conducted to self-assess self-regulated learning skills.

\section{THEORETICAL FRAMEWORK}

\subsection{Self-Regulated Learning}

Self-Regulated Learning is defined by Zimmerman [8] as a "self-directive process by which learners transform their mental abilities into academic skills. Learning is viewed as an activity that students do for themselves in a proactive way rather than as a covert event that happens to them in reaction to teaching. Self-regulation refers to selfgenerated thoughts, feelings, and behaviors that are oriented to attaining goals". SRL occurs, according to Schunk and Zimmerman [6] in three major phases: Forethought, Performance or Volitional Control, and SelfReflection.

Phase 1, Forethought, is defined as "influential processes and beliefs that precede efforts to learn and set the stage for such learning". Phase 2, Performance or Volitional Control, refers to processes that take place during learning efforts. These processes affect learner's concentration and performance. The last phase, SelfReflection, occurs after learning efforts. Self-reflection practices influence reactions to past experiences and future learning. Within each phase, specific sub-processes have been defined. Table 1 introduces these phases and sub-processes [6].

Table 1: Self-Regulation phases and sub-processes.

\begin{tabular}{|l|l|l|}
\hline \multicolumn{1}{|c|}{ Forethought } & \multicolumn{1}{|c|}{$\begin{array}{c}\text { Performance/ } \\
\text { Volitional Control }\end{array}$} & $\begin{array}{c}\text { Self- } \\
\text { reflection }\end{array}$ \\
\hline Goal setting, & Attention focusing, & Self- \\
Strategic & Self-instruction, & evaluation, \\
planning, & Self-monitoring & Attributions, \\
Self-efficacy & & Self-reactions, \\
beliefs, & & Adaptivity \\
$\begin{array}{l}\text { Goal } \\
\text { orientation, }\end{array}$ & & \\
\hline
\end{tabular}




\begin{tabular}{|l|l|l|}
\hline Intrinsic interest & & \\
& & \\
\hline
\end{tabular}

Academic self-regulated learning skills can be developed using student-centered instructional strategies such as active learning, as described by Lord et al. [3], who define it as "anything a Faculty member asks students to do in class, other than listening and taking notes, so long as the activity is related to the desired learning." Student-centered strategies such as problem/project based learning, flipped classrooms, or one-minute papers have demonstrated development of the skills mentioned in Table 1. To become lifelong learning citizens, students need to gain increasing ability and motivation to direct their own learning process while they are still in a structured classroom environment. To achieve these skills, students need instructors' guidance in the process. Therefore, creating a classroom environment designed using student-centered pedagogies aid development of SRL skills.

Examples of pedagogical activities that support development of SRL are Problem-based learning (PBL) and Project-Based learning (PjBL). PBL and PjBL have been shown to increase students' metacognitive abilities, promote critical thinking and an intrinsic goal orientation, and improve students' regulation of effort, while decreasing the amount of time students need to spend studying [7]. Active learning strategies requiring peerfeedback (e.g. peer instruction, peer assessment) and selfreflection (e.g. self-assessment, journal writing) help develop SRL as well [1].

\section{LIFELONG LEARNING GRADUATE ATTRIBUTE}

\subsection{McGill's Lifelong Learning Graduate Attributes}

The CEAB's lifelong learning graduate attribute is defined as students' "ability to identify and to address their own educational needs in a changing world in ways sufficient to maintain their competence and to allow them to contribute to the advancement of knowledge." With regards to this graduate attribute, McGill expects that its graduates: 1) acknowledge their limitations with respect to both knowledge and competence; 2) take charge of their own learning and development; 3) plan and carry out, selfdirected studies and/or research to improve their own knowledge and competence.

The indicators used to measure the Lifelong Learning graduate attribute at McGill University were adapted from Kirby's et al. publication [2]. Kirby et al. describe lifelong learners as those capable of:
- $\quad$ Setting goals (Indicator 1)

- Applying appropriate knowledge and skills to learning activities (Indicator 2)

- Engaging in self-direction and self-evaluation (Indicator 3)

- Locating required information (Indicator 4)

- Adapting learning strategies to new conditions (Indicator 5)

Although lifelong learning was assessed in different department specific courses in each program, the Faculty of Engineering decided to measure this attribute for all undergraduate students in two Faculty-wide courses: FACC 100: Introduction to the Engineering Profession and FACC 400: Engineering Professional Practice. Both direct and indirect assessments were used in these Faculty-wide courses. In the next section these direct and indirect assessments are discussed.

\subsection{Lifelong Learning Assessments}

3.2.1 Direct assessment. FACC 100: Introduction to the Engineering Profession is a first-year course all engineering students are required to take. For many students, it is the first time they are formally exposed to the concept of lifelong learning. Students, in this course, are asked to write an essay about their future engineering career. They provide a job description, including the required training and education. The students are then asked to reflect on their own personal characteristics that make them suited for this career path. The activity helps students with setting/identifying their own goals and the exercise of reflecting on their careers, which in return helps them to engage in self-direction and self-evaluation (particularly the idea of what skills they think they need to improve on or further develop to be successful). The students are given a specific rubric for what is expected regarding their self-reflection and evaluation of their own personality, interests and skills. The teaching assistant assigns a score for this activity associated with the graduate attribute indicator based on the rubric in Table 2 .

Table 2: Self-reflection Rubric.

\begin{tabular}{ll}
\hline $\begin{array}{l}\text { Exceeds } \\
\text { expectations }\end{array}$ & $\begin{array}{l}\text { Thorough evaluations of personality, } \\
\text { work habits, interests, etc., are made to } \\
\text { be suitable for such a career. } \\
\text { Multiple aspects of personal } \\
\text { development are discussed. }\end{array}$ \\
\hline Meets & $\begin{array}{l}\text { Some personal evaluations are made. } \\
\text { expectations }\end{array}$ \\
& $\begin{array}{l}\text { Some aspects of personal development } \\
\text { are made. }\end{array}$ \\
\hline Marginal & $\begin{array}{l}\text { A few aspects of personal developments } \\
\text { are made. } \\
\end{array}$ \\
& $\begin{array}{l}\text { Only limited future } \\
\text { development are discussed. }\end{array}$ \\
\hline
\end{tabular}




\section{Not Writing is barely related to the topic. demonstrated}

FACC 400 Engineering Professional Practice is a fourth-year course that is also mandatory for all engineering students. The course provides students with the opportunity to reflect on their current and future educational and training needs. The course content covers issues of local, national and global engineering related challenges. These challenges, presented as case studies, allow students to reflect on issues such as equity and ethical dilemmas they may have to face when working as engineers. This course also deepens students' awareness of the limitations of their knowledge. In this course, the lifelong learning attribute was measured based on a 300word essay that students had to write at the end of the semester in response to the following statement: Lifelong Learning is the ability to develop personal professional growth plans that reflect commitment to lifelong learning and best practices. Lifelong learners continuously access, reflect on, and integrate knowledge to remain current in educational profession and practice. How has your program at McGill given you the tools to be a lifelong learner?

3.2.2 Indirect Assessment. In addition to direct performance measurements by course instructors, a selfassessment (in a survey format) was conducted to measure students self-regulated learning skills. The selfassessment was answered by all students registered in both FACC 100 and FACC 400. The purpose of this selfassessment is to compare students' SRL skills at the beginning (FACC 100) and at the end of their program (FACC 400). Doing so enables a comparison of their progress in the lifelong learning graduate attribute after the 4 years of engineering education. The self-assessment was designed using the Motivated Strategies for Learning Questionnaire (MSLQ).

\subsection{Motivated Strategies for Learning Questionnaire (MSLQ)}

The instrument used to measure engineering students' learning strategy usage was Pintrich's et, al. Motivated Strategies for Learning Questionnaire (MSLQ) [5]. This Likert-scaled self-report instrument consists of 31 items that measure motivational orientations and learning strategies. For measuring SRL skills, 12 of the 31 questions were used.

The survey had a scale ranging from 1 to 5,1 being 'not at all true of me' and 5 'very true of me.' The students from FACC 100 (first-year students) were asked to complete the survey 2 weeks after the beginning of the course. FACC 400 (fourth-year students) completed the survey during the last week of the course. The decision of when to conduct the survey was made to ensure SRL skills measured had been obtained before attending McGill and after completing the program. Both groups responded to the survey via McGill's learning management system.

The questions used in the survey were:

1. During class time I often miss important points because I'm thinking of other things.

2 . When reading for my courses, I make up questions to help focus my reading.

3. When I become confused about something I'm reading for a class I go back and try to figure it out.

4. If course readings are difficult to understand, I change the way I read the material.

5. Before I study new course material thoroughly, I often skim it to see how it is organized.

6. I ask myself questions to make sure I understand the material I have been studying in class.

7. I try to change the way I study in order to fit the course requirements and the instructor's teaching style.

8. I often find that I have been reading for a class but don't know what it was all about.

9. I try to think through a topic and decide what I am supposed to learn from it rather than just reading it over when studying for a course.

10. When studying for a course I try to determine which concepts I don't understand well.

11. When I study for a course, I set goals for myself in order to direct my activities in each study period.

12. If I get confused taking notes in class, I make sure I sort it out afterwards.

\section{CONCLUSIONS}

Activities designed to create awareness on lifelong learning followed the phases of Self-Regulated Learning suggested by Schunk and Zimmerman [6]: Forethought, Performance or Volitional Control, and Self-Reflection.

The essay assignment written by first-year students (FACC 100 students - reflection on future engineering careers) was an opportunity for students to reflect on the training and educational needs required to succeed in the engineering job market (technical and professional skills). This assignment can be categorized in the Forethought phase.

The essay written by FACC 400 students (How has your program at McGill given you the tools to be a lifelong learner?) allowed students to reflect on their previous three/four years as undergraduate engineering learners. Soon-to-graduate students had the opportunity to think on how prepared they are to join a constantlychanging workforce. This essay assignment responds to characteristics described in the Self-Reflection phase.

The survey conducted with both FACC 100 and FACC 400 groups used questions from the MSLQ instrument. 
MSLQ was created using SRL as a theoretical framework. The 12-item survey encompasses all three phases of SRL, having a stronger emphasis on the Performance/Volitional Control phase.

In the reflective writing exercises, students generally rate very highly in the direct assessment of lifelong learning skills. However, in the indirect self-assessments about $40 \%$ of students consistently rate their skill level as "meeting expectations", or "below expectations". This represents an opportunity to design activities to improve student performance in this area.

The assignments mentioned in this paper are a first attempt to bring awareness on the importance of Lifelong Learning to all community members of the Faculty of Engineering at McGill University. We are aware of the challenges of measuring this specific attribute. For this reason, we are obliged to further develop evidence-based instructional strategies that promote the development of Self-Regulated Learning skills among our current student population.

\section{Acknowledgements}

The authors would like to thank eLATE - Enhancing Learning and Teaching in Engineering - from McGill University which provided support in conducting the different activities mentioned in this paper.

\section{References}

[1] Bose Jayakumar and Zed Rengel, "A model formative assessment strategy to promote student-centered selfregulated learning in higher Education," US-China Education Review, vol. 6, no. 12, pp. 29-35, December 2009.

[2] John R. Kirby, Christopher Knapper, Patrick Lamon, and William J. Egnatoff. "Development of a scale to measure lifelong learning." International Journal of Lifelong Education, vol. 29, no. 3, pp. 291-302, May-June 2010.

[3] Susan M. Lord, Michael J. Prince, Candice R. Stefanou, Jonathan D. Stolk, and John C. Chen, "The effect of different active learning environments on student outcomes related to lifelong Learning," International Journal of Engineering Education, vol. 28, no. 3, pp. 606-620, February 2012.

[4] Linda Nilson. Creating Self-Regulated Learners: Strategies to Strengthen Students Self-Awareness and Learning Skills. Sterling, VA: Stylus Publishing, LLC., 2013 (1st ed.), XXX pp. \{ISBN: 978-1-57922-867-5\}

[5] Paul R. Pintrich, David A. F. Smith, Teresa Garcia, Wilbert J. McKeachie, "A manual for the use of the Motivated Strategies for Learning Questionnaire (MSLQ)." The Regents of the University of Michigan, 1991
[6] Dale Schunk and Barry J. Zimmerman, eds. Selfregulated learning: From teaching to self-reflective practice. New York, NY: Guilford Press, 1998. [ISBN 157230-306-9\}

[7] Sungur Semra, and Ceren Tekkaya. "Effects of problembased learning and traditional instruction on self-regulated Learning," The journal of educational research, vol. 99, no. 5, pp. 307-320, 2006.

[8] Barry J. Zimmerman, (2002). "Becoming a self-regulated learner: An overview", Theory into practice, vol. 41, no. 2, pp. 64-70, May 2002. 